\title{
Performance of Crumb Rubber Incorporated Ferro Geopolymer Panels under Flexure
}

\author{
Mohana R, Muthukumar A
}

\begin{abstract}
This research work presents the overview of geopolymer mortar application into the ferro cement panel with the incorporation of crumb rubber and Nano fly ash. The geopolymer mortar is prepared by using industrial wastes as a base material such as fly ash and ground granulated blast furnace slag (GGBFS) which generally helps to reduce the level of $\mathrm{CO}_{2}$ emission. Also, the recycled tyre crumb rubber is utilized as a sustainable innovative construction material which is used a partial substitution for sand upto 5\% for enhancing the ductility without any strength degradation. These reduces land fill problems and ground water quality degradation problems. Crumb rubber has the ideal capacity to absorb energy from static and other kind of loads. The geopolymer binder preparation is done by utilizing material such as fly ash, GGBFS, alkaline liquid made of $\mathrm{NaOH}$ and $\mathrm{Na}_{2} \mathrm{SiO}_{3}$, Nano fly ash. The Nano fly ash is used as an additive which helps in increasing the strength and durability of the element by its pore filling capability. This project aims to enhance the strength of fly ash based geopolymer mortar with the help of GGBFS incorporation. The molarity of alkaline activator, solution to binder ratio and silicate to hydroxide ratio is fixed as 12, 0.4 and 1.5 throughout the process. The mortar cubes and panels were heat cured under hot air oven at $80^{\circ} C$ for 48 hours. The mechanical behavior of geopolymer mortar is assessed by compressive strength test water absorption test. The panel is made of high strength geopolymer mortar and expanded metal mesh with chicken mesh for obtaining higher energy absorption capacity with good deforming ability and less crack pronouncement. The investigation involves finding the initial crack load, ultimate failure load and residual flexural strength ratio. The results show that the tyre inclusion enhances the flexural strength of the ferro geopolymer panel by means of its ductile enhancing capacity.

Index Terms: Geopolymer mortar, Fly ash, GGBFS, Crumb rubber, Nano fly ash and Flexure.
\end{abstract}

\section{INTRODUCTION}

Geopolymer is an innovative eco-friendly material for obtaining sustainable development with enhanced strength properties for obtaining green environment. Geopolymer reduces the amount of carbon dioxide gas emission whereas cement manufacturing process involves high amount of $\mathrm{CO}_{2}$ emission [7].

Revised Manuscript Received on December 05, 2019.

Dr.R.Mohana., Assistant Professor(SG) , Department of Civil Engineering,Mepco Schlenk Engineering College, Sivakasi.

Muthukumar A, M.E., Structural Engineering, Mepco Schlenk Engineering College, Sivakasi.
In previous study noticed that there is a low level of loss on ignition values for geopolymeric materials. The OPC manufacture also flex out nitrogen and Sulphur oxide gases which is the main sources for global warming and acid rain problems. The cement manufacture alone makes $65 \%$ of global warming and it emits 1.35 billion tons of carbon dioxide gas into the environment. The geopolymer requires 1.6GJ work energy with $80 \%$ reduction in $\mathrm{CO}_{2}$ emission whereas the cement manufacture needs 4GJ work energy [1],[3]. The geopolymerization involves the reactions of chains of inorganic molecule between polymer-based materials. The benefits by using geopolymer are higher compressive strength, earlier strength development, acid resistance, fire resistance, low creep and shrinkage, crack reduction and lower porosity [6], [9]. The sodium-based materials are mostly used for preparing an alkaline liquid because of their low cost but the potassium-based materials are slightly higher in cost with increased strength. The industrial byproducts such as fly ash, GGBFS, metakaolin and RHA etc. are used in civil structural application, in which some of them are utilized and remaining are disposed into the land [11]. This would create major problems such as air pollution, ground water pollution and land pollution. Totally, 800 million tons of fly ash is produced in which half portion is utilized per annum [2]. GGBFS is a waste composed from iron industries which has high pozzolanic reactivity and alkali activation. It only emits $7 \%$ of $\mathrm{CO}_{2}$ emission of cement manufacture [7]. The main composition of the fly ash and GGBFS are alumina, silica and oxygen products which plays an important role in strength development of geopolymer which forms the C-A-S-H gel and N-A-S-H gel. The fly ash is categorized into low calcium (class-F) and high calcium (class-C) fly ash. The one ton of low calcium fly ash used to produce $2.5 \mathrm{~m}^{3}$ of geopolymer concrete [6]. The fly ash based geopolymers are having resistance to alkali-aggregate reaction due to their lower calcium content. The compressive strength directly relates with the amount of calcium present in the fly ash and its fineness. For early age strength development, the high calcium fly ash is used. The mineralogical classification of fly ash is amorphous/glassy (pozzolanic), inert, active, mixed phases and crystalline. The mix design of geopolymer involves molarity of $\mathrm{NaOH}$, silicate to hydroxide ratio, solution to binder ratio and water to solid ratio. Usually 8 to 14 molarity of $\mathrm{NaOH}$ is preferred but for optimum results 12 to 14 molarity is taken.

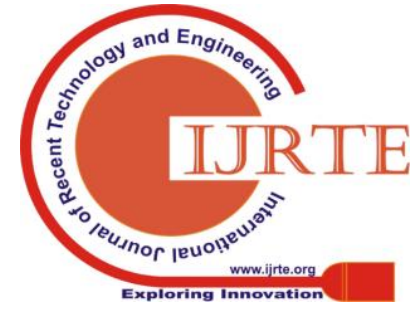


The method of curing usually adopted for geopolymers are heat curing, steam curing and ambient curing. The efficiency of heat curing is 1.5 times higher than steam curing. The temperature control maintained in the range between $60^{\circ} \mathrm{C}$ to $80^{\circ} \mathrm{C}$. By increasing the curing period, strength can be incremented. The ambient curing can be achieved by incorporating GGBFS into the fly ash based geopolymer mix.

The tyre production is reached 17 million per annum [2]. The high mechanized ball mill is used to create shredded rubber, crumb rubber and powder rubber and the separation is done accordingly. When crumb rubber incorporating into the concrete or mortar, the disposal problem of tyre on land is automatically reduced. The presence of heavy metal affects the ground water quality standards and the non-bio-degradability of tyre leads to land pollution. The

crumb is used instead of sand in many researches which could be an alternative way to reduce cost of natural sand and its transportation, over depletion of natural resources. [7]. The energy absorption is important for element when they may be subjected to static, dynamic and fatigue loads. Hence, there is a need for high ductile and higher energy absorbing element. The primary objective of this flexure study was to investigate the effectiveness of various combination of geopolymer mix with appropriate mesh layers.

\section{EXPERIMENTAL PROCEDURE}

\section{A. Materials}

Geopolymer is an inorganic polymer material which is produced by a material composed from industries such as fly ash, GGBFS, metakaolin, etc. with the alkaline activator liquid which induces the reaction of alumina and silica. The fly ash, GGBFS, crumb rubber, sand, alkaline liquid composed of sodium hydroxide and sodium silicate, and water is used in this research work to produce geopolymer binder. The fly ash is obtained from Tuticorin thermal power plant where the fly ash is produced by the coal combustion process in electric furnace. Based on the $\mathrm{CaO}$ content, there are two types class-C (high calcium) fly ash and class-F (low calcium) fly ash. In this research, low calcium fly ash is used. The GGBFS is a by-product of steel industries by quenching, grinding of coarser particle to get fine nature of angular particles with glassy form. The crumb rubber particles ranging from $75 \mu$ to $4.75 \mathrm{~mm}$ is used. The river sand confirming to zone-II (IS 383-1987) is used with specific gravity and fineness modulus value 2.65 and 2.88 respectively.

Alkaline activator made of commercially available $\mathrm{NaOH}$ and $\mathrm{Na}_{2} \mathrm{SiO}_{3}$ is used to induce geopolymerization process. Sodium hydroxide flakes with $98 \%$ purity and sodium silicate with mass ratio $\left(\mathrm{SiO}_{2} / \mathrm{Na}_{2} \mathrm{O}\right)$ is of two with the sodium silicate liquid $\left(\mathrm{Na}_{2} \mathrm{O}=14.7 \%, \mathrm{SiO}_{2}=29.4 \%\right.$ and $\mathrm{H}_{2} \mathrm{O}=55.9 \%$ ). The high amount of fly ash and low $\mathrm{Na}_{2} \mathrm{O}$ in activator gives high bond strength between mesh and geopolymer, but high ash content leads to more chances for brittle failure [35]. The silicate to hydroxide ratio and solution to binder ratio is taken as 1.5 and 0.4 respectively throughout the process. The $\mathrm{NaOH}$ flakes are mixed with distilled water which does not affect alkaline reactivity for preparing $\mathrm{NaOH}$ solution. For 1 molarity of $\mathrm{NaOH}$ solution $40 \mathrm{~g}$ of $\mathrm{NaOH}$ solid is used for 1 liter of water.

Table- II: Chemical constituents of fly ash and GGBFS

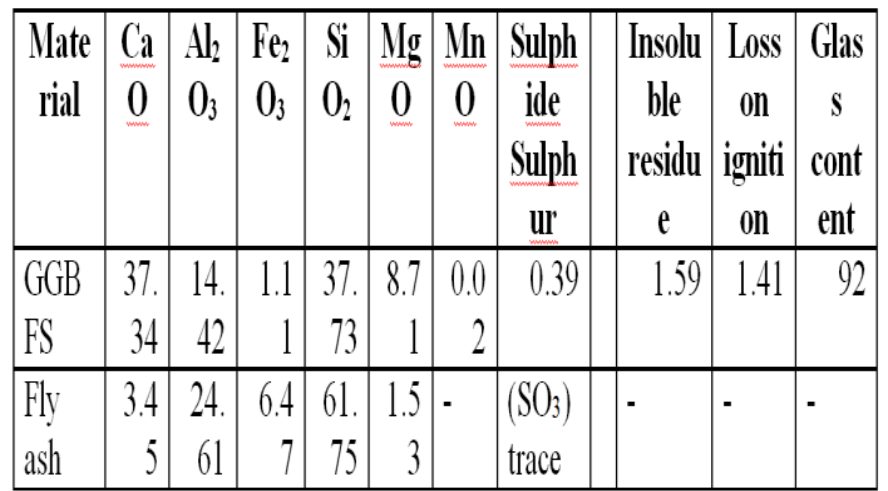

In this proposed work, the $12 \mathrm{M}(480 \mathrm{~g} \mathrm{NaOH} /$ lit) or $(361 \mathrm{~g}$ $\mathrm{NaOH} / \mathrm{kg}$ ) of $\mathrm{NaOH}$ solution is made and left for 2 hours. Then sodium silicate is added to $\mathrm{NaOH}$ solution to prepare an alkaline solution. The alkaline solution should be prepared 24 hours prior. This helps to ensure complete heat dissipation and proper dissolution of chemicals.

The synthesizing of Nano fly ash is done with the help of high mechanized ball mill. Ball mill is a cylindrical device used for grinding or mixing of materials such as ores, chemicals, ceramic raw materials and paints, etc. Ball mill is works under the principle of impact and attrition. The 50 numbers of tungsten carbide balls each consists of 8 grams weight were introduced to ground 40-gram fly ash for 4 hours grinding time. This process is made by considering fly ash: ball ratio of $1: 10$. The fly ash taken was sieved through 45-micron sieve and passing materials are taken. After and before the synthesis process, the SEM analysis is done to check and confirm the size ranges of particles. The Nano fly ash is obtained with sub-micron particle ranges as shown in figures.

The Scanning Electron Microscope (SEM) image of fly ash and Nano fly ash is given in Figs. 1, 2 \& 3 respectively.

The fly ash particle size distribution ranges from $5 \mu \mathrm{m}$ to $50 \mu \mathrm{m}$ with spherical particle is obtained. The treated crumb rubber ranges from $5 \mu \mathrm{m}$ to $50 \mu \mathrm{m}$ with granular size particle is obtained. For Ferro cement casting, meshes used are expanded metal mesh (EMM) for their high ductility with chicken mesh (CM) layers. The above mentioned meshes are made of galvanized iron material. The crack pronouncement is less during the loading condition with the ductile capacity of the specimen is superior in performance of loading. EMM make an improvement in the structural indicators such as cracking loads, ultimate loads and ductility of panel [19]. The number of mesh layer contributes to the effective strength achievement only upto a certain limit behind that there will be no effect.

Table- I: Dimensions of the mesh reinforcement

\begin{tabular}{|l|l|l|l|l|}
\hline Mesh type & \multicolumn{1}{|c|}{ Shape } & $\begin{array}{c}\text { LWD } \\
(\mathbf{c m})\end{array}$ & $\begin{array}{c}\text { SWD } \\
(\mathbf{c m})\end{array}$ & $\begin{array}{c}\text { Thickness } \\
(\mathbf{m m})\end{array}$ \\
\hline EMM & Diamond & 1.7 & 0.9 & 0.75 \\
\hline CM & Hexagonal & 2.6 & 2.0 & 0.4 \\
\hline
\end{tabular}

LWD - long way dimension (length of mesh opening), SWD short way dimension (width of mesh opening). 


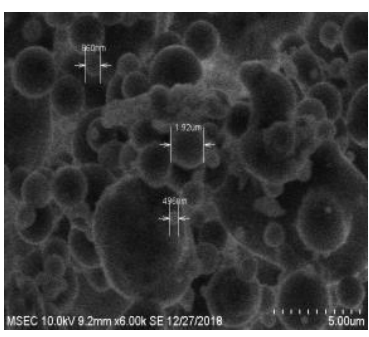

Fig. 1. Fly ash

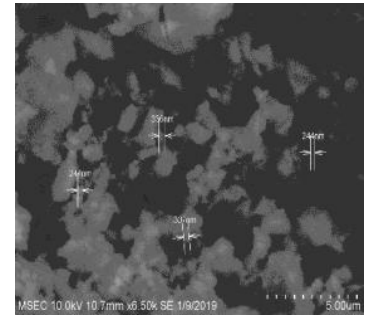

Fig. 2. Nano fly ash
Table- III: Composition of GGBFS, fly ash and crumb rubber

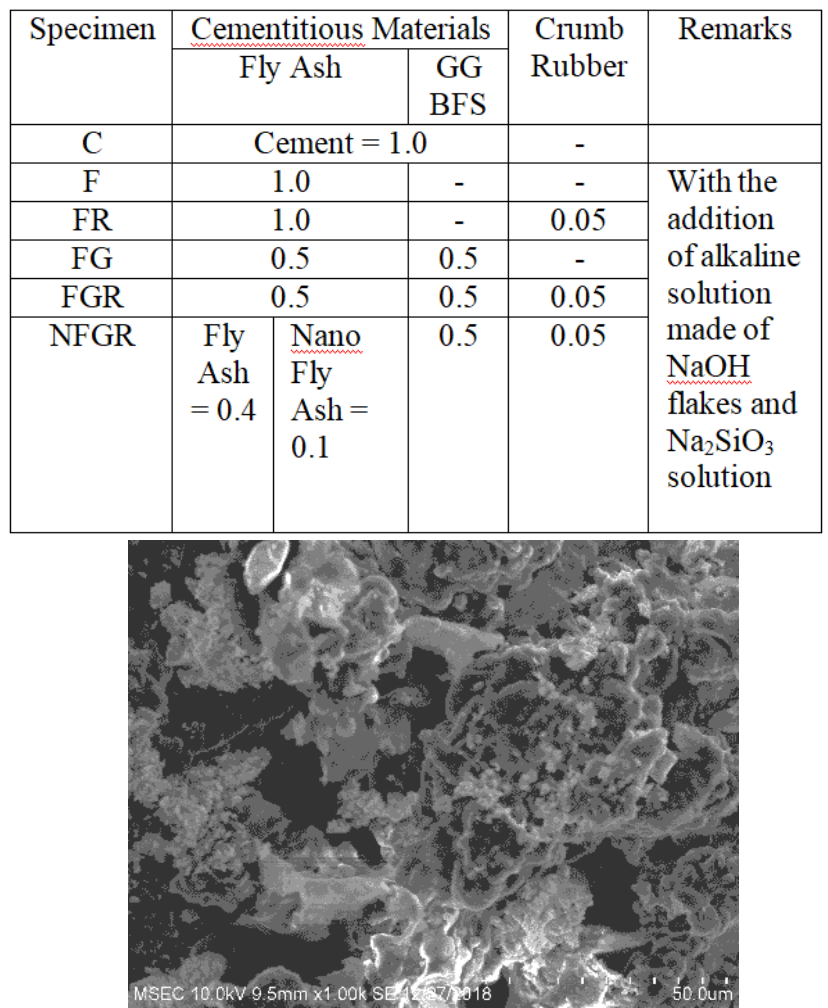

Fig. 3. Treated crumb rubber

\section{B. Mortar Mix Details}

The mortar mix ratio of 1:2 (i.e. unit part of cementitious materials with 2 parts of fine aggregate) is followed throughout the process. The solution to binder ratio, silicate to hydroxide ratio and $\mathrm{NaOH}$ molarity is fixed as $0.4,1.5$ and 12 respectively throughout the entire process. The sand is replaced by optimized amount of 5\% crumb rubber for ductility enhancement. The additive Nano fly ash of $10 \%$ is used for enhancing the microstructure property. Also, the control specimen was made with the water-cement ratio of 0.30 . The $2.0 \%$ super plasticizer by the cement weight is added to increase the workability of mix. Higher sand with lesser binder results in reducing geopolymerization process. By optimizing the alkali content, the mortar with better strength can be achieved [21]. The $\mathrm{NaOH}$ molarity, GGBFS content, fineness, $\mathrm{NaOH}$ content, curing temperature, solution to binder ratio and water to solid ratio has direct link to the carbonation resistance and strength enhancement of geopolymer [6], [9].

\section{Surface Modification of Crumb Rubber}

The crumb rubber surface can be altered by oxidation followed by sulphonation using the methods of treatments such as: 1. Acid etching method, 2. Plasma pretreatment, 3. Coupling agent methods. The usually followed treatment methods are $\mathrm{NaOH}$ treatment, Organo clay treatment, $\mathrm{KmnO}_{4}$ treatment and Silane coupling agent method, etc. The $\mathrm{NaOH}$ treatment is done because of its high effective surface modification, simplicity and minimal cost. Treated crumb rubber inclusion results in higher compressive and flexure strength rather than that of non-treated rubber included specimen. The crumb rubber is immersed in $1 \mathrm{~N} \mathrm{NaOH}$ solution for 30 minutes. After that the rubbers are water washed to remove the presence of $\mathrm{NaOH}$ residue. The moist rubber is free dried under sun light with ambient condition. 1lit of $\mathrm{NaOH}$ solution may require for treating $1 \mathrm{~kg}$ of crumb rubber. The SEM image of treated crumb rubber is shown in Fig. 6.

\section{Methods Adopted for Casting and Testing}

The materials such as fly ash, GGBFS and sand are dry mixed for 3 to 4 minutes followed by wet mix for 4 to 6 minutes to produce homogeneous mixture. The geopolymerization is activated by addition of alkaline activator solution. The required free water is added for obtaining workable and flowable mix with the addition of $2 \%$ super plasticizer. Then, the mortar is filled in cube mold (volume $=7.06 \mathrm{cmX} 7.06 \mathrm{cmX} 7.06 \mathrm{~cm}$ ) by 3 layers and each layer is ramped 25 times for well compaction. The hot air oven curing is followed for 48 hours at $80^{\circ} \mathrm{C}$.

The Ferro cement panel is made by using expanded metal mesh (2 layers), chicken mesh (2 layers) and geopolymer mortar. The panel mold is made of steel angle with the size of $230 \mathrm{mmX} 230 \mathrm{mmX} 25 \mathrm{~mm}$ with open top and bottom is rest on base plate. The chicken mesh and expanded metal mesh is bundled with binding wire without gap. For lubrication purpose grease and oil is applied into mold to obtain proper finishing and easy dismantle of panel. Then mesh is placed with the cover of $5 \mathrm{~mm}$ and covered by mortar. The fresh mortar layer is well compacted with the help of trowel itself. Finally, the panel is finished with smooth surface and dismantled. Then the panel is demolded and allowed for curing process. The panel categories are: C- Control panels, F- fly ash based geopolymer panels, FG- fly ash and GGBFS based geopolymer panels, FR- fly ash and crumb rubber based geopolymer panels, FGR- fly ash, GGBFS and crumb rubber based geopolymer panels, NFGR- Nano fly ash, fly ash, GGBFS and crumb rubber based geopolymer panels. The yield strength of mesh is found with the help of tensile tester apparatus. Volume fraction of reinforcement is calculated as follows:

(1)

$$
\mathrm{V}_{\mathrm{t}}=\mathrm{Nw}_{\mathrm{r}} / \mathrm{h} \delta_{\mathrm{r}} .
$$

Specific surface of reinforcement is given below:

$$
\begin{array}{lllll}
\mathrm{S}_{\mathrm{r}} & = & 4 \mathrm{~V}_{\mathrm{t}} & / & \mathrm{d}_{\mathrm{b}}
\end{array}
$$

(2)

Where, N- no. of layers, $d_{b}$-diameter of wires, $\mathrm{w}_{\mathrm{r}}$-unit wt. of reinforcing mesh, $\delta_{\mathrm{r}^{-}}$density of reinforcing material, hthickness of ferrocement element.

Table- IV: Volume fraction, specific surface and yield strength of mesh reinforcement

\begin{tabular}{|l|l|l|l|}
\hline Mesh type & \multicolumn{1}{|c|}{$\mathbf{V}_{\mathbf{t}}(\boldsymbol{\%})$} & $\mathbf{S}_{\mathbf{r}}(\boldsymbol{\%})$ & $\begin{array}{c}\text { yield strength } \\
(\mathbf{M P a})\end{array}$ \\
\hline $\mathrm{EMM}$ & 0.944 & 5.035 & 528 \\
\hline $\mathrm{CM}$ & 0.123 & 1.230 & 326 \\
\hline
\end{tabular}




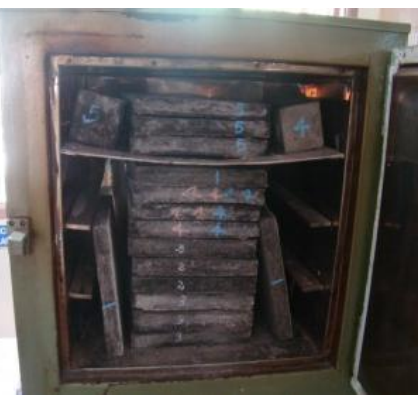

Fig. 4. Oven curing

\section{E. Compressive Strength}

This test is performed to check the required compressive strength is attained for GP mortar when compared to control specimen. The GP mortar cube was heat cured and control specimen are water cured for 28 days at room temperature. After completion of curing, the cubes are dried in an air and tested on $1000 \mathrm{KN}$ capacity universal testing machine as shown in Fig. 11. The compression loading is continued till the failure of the specimen. The test is conducted as per IS 4031 (part 6)-1988 guidelines.

\section{F. Water Absorption Test}

This test is made in accordance with ASTM C 642 code provisions. Initially, the cubes were set in oven at $100^{\circ} \mathrm{C}$ for 24 hours. The weight is taken with the accuracy of one gram. Then the specimen is immersed in water for 24 hours. The cubes are taken out from and wipe out with a cloth and the weight of mortar specimen is taken. From these two weights, the percentage of water absorption percentage is calculated as in equation (3).

$$
\mathrm{W}_{\mathrm{ab}}=((\mathrm{B}-\mathrm{A}) / \mathrm{A}) \times 100 \%
$$

Where, $\mathrm{W}_{\mathrm{ab}}-$ Water absorption (\%), A- Initial weight of specimen, B- Moist weight of specimen.

\section{G. Flexure Test}

The center point flexural loading is applied on a panel with the simply supported end condition. The universal testing machine is used for performing this flexure test. The load is applied at middle portion of the panel as incase of three-point loading. The flexural loading is continued until the failure of the panel. The flexure strength and corresponding structural behavior are to be investigated. The test procedure is done according to ASTM D 3043 - 00e guidelines. The investigation involves first crack load, failure load, deflection, cracking pattern, etc. The influencing factors of first crack strength are type, geometry and specific surface of the reinforcement used in the panel fabrication. Pure bending equation for ferro cement is used for finding theoretical flexural resistance of the panel.

$\left(\mathrm{M} /\left(\mathrm{f}_{\mathrm{c}}{ }^{\prime} \mathrm{bh}^{2} \eta\right)\right)=0.005+0.422\left(\left(\mathrm{~V}_{\mathrm{t}} \mathrm{f}_{\mathrm{y}}\right) / \mathrm{f}_{\mathrm{c}}{ }^{\prime}\right)-0.0772\left(\left(\mathrm{~V}_{\mathrm{t}} \mathrm{f}_{\mathrm{y}}\right)\right.$ $\left./ \mathrm{f}_{\mathrm{c}}{ }^{\prime}\right)^{2}$

(4)

$\mathrm{M}=\left(\left(\mathrm{f}_{\mathrm{cr}} \mathrm{XI}_{\mathrm{gr}}\right) / \mathrm{y}_{\mathrm{t}}\right)$

(5)

The experimental flexure response is calculated as follows:

$\mathrm{M}=(\mathrm{PL} / 4)$
$\mathrm{EI}=\left(\mathrm{PL}^{3} / 48 \Delta\right)$

(7)

Youngs modulus can be found by using following relationship.

$\mathrm{E}=-0.60 \mathrm{M}^{3}+29.75 \mathrm{M}^{2}-509.70 \mathrm{M}+4068.47$

(8)

Where, M- percentage of crumb rubber added.

$\mathrm{E}=-0.60 \times 5^{3}+29.75 \times 5^{2}-509.70 \mathrm{M}+4068.47=2188.72$ MPa.

Where, $\mathrm{M}$ - observed flexure strength, $\mathrm{M}_{\mathrm{t}}$-theoretical flexural strength, EI-bending stiffness, P-flexure load, $\Delta$ - deflection, $\mathrm{f}_{\mathrm{c}}$ '-mortar compressive strength, $\mathrm{b}$-width of panel, h-thickness of panel, $\eta$-global efficiency factor of mesh in loading direction, $\mathrm{V}_{\mathrm{t}}$-volume fraction of the mesh, $\mathrm{f}_{\mathrm{y}}$-yield strength of

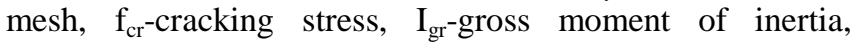
$\mathrm{y}_{\mathrm{t}}$-distance from the neutral axis, L-unsupported length of the panel.

Here, the cracked section analysis is used for theoretical flexure strength determination.

$$
\begin{aligned}
\mathrm{mm}^{4} & \\
\mathrm{y}_{\mathrm{t}} & =(25 / 2)=12.5 \mathrm{~mm} \\
\mathrm{f}_{\mathrm{cr}} & =0.7 \mathrm{X} \sqrt{\mathrm{f}_{\mathrm{ck}}}
\end{aligned}
$$$$
\mathrm{I}_{\mathrm{gr}}=\left(\mathrm{Bh}^{3}\right) / 12=\left(\left(230 \times 25^{3}\right) / 12=299479.167\right.
$$

Table- V: Theoretical flexural resistance of panels

\begin{tabular}{|c|c|c|}
\hline Panels & $\mathbf{f}_{\text {cr }}(\mathbf{M P a})$ & $\mathbf{M}_{\mathbf{t}}(\mathbf{K N}-\mathbf{M})$ \\
\hline $\mathrm{C}$ & 3.5 & 0.0839 \\
\hline F & 3.770 & 0.0903 \\
\hline FG & 4.082 & 0.0978 \\
\hline FR & 3.671 & 0.0880 \\
\hline FGR & 3.978 & 0.0953 \\
\hline NFGR & 4.141 & 0.0992 \\
\hline
\end{tabular}

\section{RESULTS AND DISCUSSIONS}

A) Bonding Nature

Previous study states that the geopolymer made of fly ash and GGBFS gives good bonding nature. The crumb rubber incorporation would reduce the bonding between the substrate. By modifying the crumb rubber surface, the bonding can be enhanced. The $\mathrm{NaOH}$ treatment is used for modifying the surface of crumb rubber as rough. Then, the bonding is automatically enhanced between crumb rubber and geopolymer substrate. The presence of $\mathrm{NaOH}$ in geopolymer alkaline liquid will also leads to some added advantage for crumb rubber surface modification. The fracture of particles from mortar substrate is fully rectified after GGBFS addition and crumb rubber treatment which could be seen by naked visible eye. The high bonding is proved by compression test results varies $8.33 \%$ to $20.5 \%$ between fly ash and GGBFS incorporated mortar with treated crumb rubber additives.

\section{B) Compressive Strength Test}

For the control mortar specimen, the sufficient strength is achieved as described in the mix proportion. The compressive strength of geopolymer mortars are higher than control mortar. The compressive strength of fly ash GGBFS based geopolymer is $8.33 \%$ to $20.5 \%$ higher than fly ash based geopolymer due to the presence of reactive alumina in GGBFS. The increment in compressive strength is due to the formation of N-A-S-H gel and $\mathrm{C}-\mathrm{S}-\mathrm{H}$ gel formation along with the silico-aluminate structure. The compressive

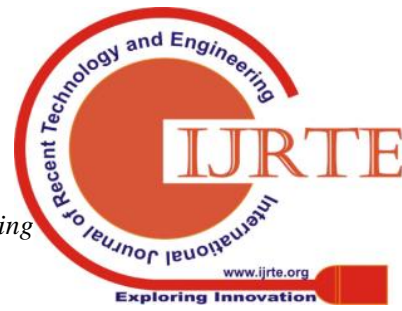


strength directly related to the molarity of $\mathrm{NaOH}$ solution and amount of GGBFS which forms more compacted microstructure in geopolymer mortar [23]. The rubber inclusion reduces the compressive strength which could be compensated by $10 \%$ Nano fly ash addition. The compressive strength of control and various geopolymer are represented in the following table.

Table- VI: Mortar characteristic compressive strength and water absorption percentages

\begin{tabular}{|l|l|l|}
\hline \multicolumn{1}{|c|}{ Specimen } & \multicolumn{1}{|c|}{$\begin{array}{c}\text { Compressive strength } \\
\text { (MPa) }\end{array}$} & \% of water absorption \\
\hline 1. control & 24 & 5.20 \\
\hline 2.a) F & 30 & 7.46 \\
\hline 2.b)FG & 32.5 & 6.85 \\
\hline 3.a) FR & 26.5 & 9.5 \\
\hline 3.b)FGR & 31.95 & 8.30 \\
\hline 4.NFGR & 34 & 7.5 \\
\hline
\end{tabular}

\section{C) Water Absorption Test}

Water absorption test are used to investigate the permeable and porous medium of a structure and indirectly evaluate the durability of a homogeneous material. The control specimen having less water absorption rather than geopolymer specimens. The water absorption percentage of geopolymer specimens are irrespective with the mix type, but it is in the acceptable range. The crumb rubber addition obviously increases the water absorption percentage but the Nano fly ash overcome this problem by its pore filling ability. The limited water absorption percentage is $10 \%$ as per ASTM C642 provisions

\section{D) Flexure Test}

The single point center flexural loading test is applied for panels. The test involves the findings of first crack strength and ultimate strength to cause initial crack generation and failure of panel. Based on the flexure test results the residual flexural strength is calculated for each panel. The values obtained are more or less equal to the theoretical prediction with least error. The crack pattern was indicated with yellow lines.

Table- VII: Flexure response of the panels

\begin{tabular}{|c|c|c|c|c|c|c|c|}
\hline Panels & $\begin{array}{c}\text { First } \\
\text { crack } \\
\text { load } \\
(\mathrm{KN})\end{array}$ & $\begin{array}{c}\text { Ultimate } \\
\text { failure } \\
\text { load (KN) }\end{array}$ & $\begin{array}{l}\text { Deflection } \\
\text { (mm) }\end{array}$ & $\begin{array}{c}\text { M (KN- } \\
\text { M) }\end{array}$ & $\begin{array}{l}\text { M/ } / \\
\text { Mt }\end{array}$ & $\begin{array}{c}\text { Bending } \\
\text { stiffness } \\
\left(\mathrm{N}-\mathrm{mmm}^{2}\right) \\
\mathrm{X} \mathrm{10^{6 }}\end{array}$ & $\begin{array}{c}\text { Residual } \\
\text { flexure } \\
\text { strength } \\
\text { ratio }\end{array}$ \\
\hline $\mathrm{C}$ & 1.67 & 2.19 & 17 & 0.1200 & 1.43 & 28.58 & 131 \\
\hline F & 1.5 & 2.1 & 19 & 0.1155 & 1.28 & 24.52 & 1.4 \\
\hline FG & 1.75 & 2.54 & 18 & 0.1397 & 1.43 & 31.30 & 1.45 \\
\hline FR & 1.76 & 2.4 & 21 & 0.1320 & 1.5 & 25.35 & 1.36 \\
\hline FGR & 1.9 & 2.85 & 24 & 0.1568 & 1.65 & 26.34 & 1.5 \\
\hline NFGR & 2.05 & 3.12 & 22 & 0.1716 & 1.73 & 31.46 & 1.52 \\
\hline
\end{tabular}

There is no distinctive failure which denotes the mesh holding capability of different fragments together during flexural loading. The mesh contributes to the bending behavior with better deform ability as their crack pattern is in the form of fine and well distributed cracks. The specimens are more ductile and fail by flexure with lesser fine cracks having closer width.

The first crack load for NFGR panel is 1.24 times higher than the control panel whereas the ultimate crack load is 1.42 times higher than the control panel. The deflection is notified that indicates lesser deflection for control panel than GP panels. This is due to the ductile enhancing capacity of meshes and mortar. The residual strength ratio for GP panel is approximately equal to 1.5 . The flexure strength is 1.35 to 1.7 times higher than the theoretical response of panels.

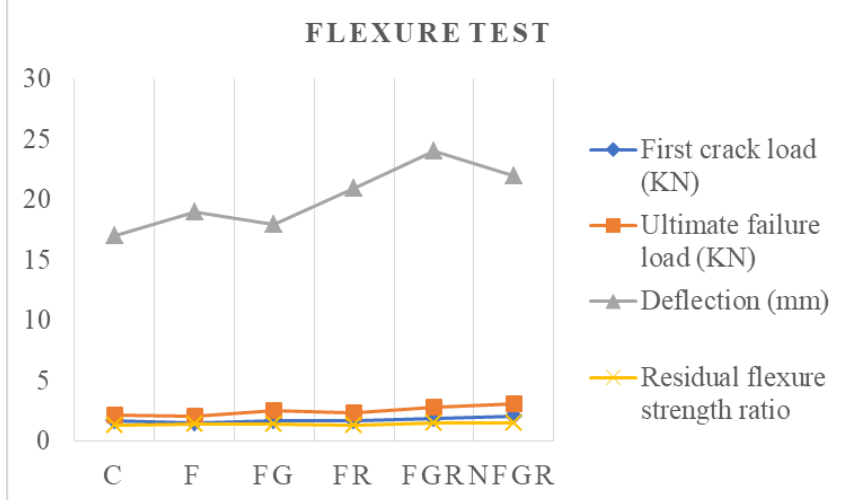

Fig. 6. Variation of flexure response of the panels E) Crack Pattern

Crack pattern refers to the material fracture in engineering applications or the patterns formed by various types of cracks with different nature. While applying the flexural load on the panels, the three stages involves cracking followed by yielding followed by ultimate failure. When the material offers some resistance results in initial crack formation. At yielding stage, the meshes are contribute more to take over loads. The ultimate stage refers to the failure of panels with the formation of complex crack propagation and crack opening.

The lesser crack pronouncement is noticed in rubber included geopolymer panels with higher flexure strength. The behavior of panels during loading is linear upto tensile crack formation from the bottom of the panel. Then crack is propagated through the thickness of the panel and appeared on the top surface. From the results, there is a large deformation with higher flexure strength which exhibits ductility enhancement.

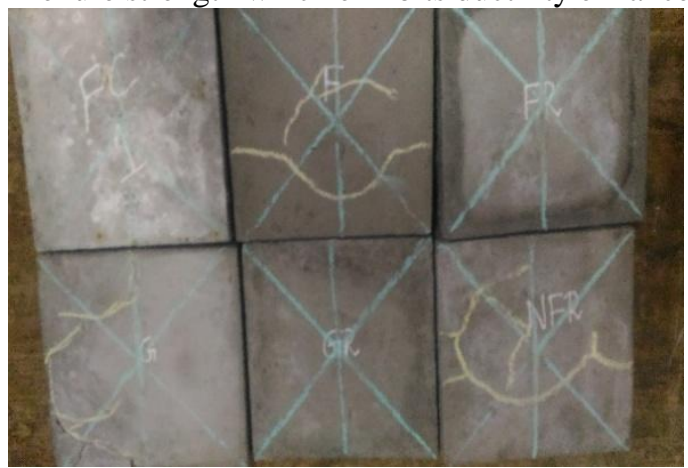

Fig. 7. Typical crack pattern on top surface of panels 


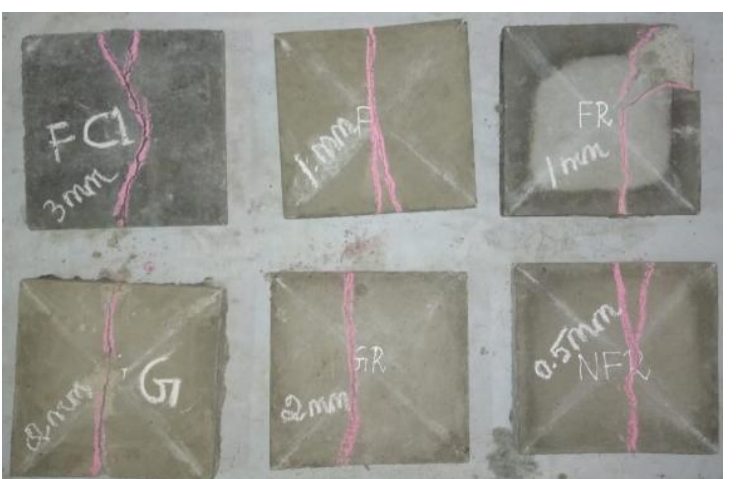

Fig. 8. Crack pattern on bottom surface of panels

The failure is first occurred by yielding of mesh followed by bulging of mortar. The specimens are more ductile and fail by flexure with lesser fine cracks having closer width. The crack pattern was indicated with yellow lines. From the results, there is a large deformation with higher flexure strength which exhibits ductility enhancement. The fine cracks having the reduced width has been observed. On the top surface of the panel, the observed cracks are fine cracks called as hairline cracks which is having crack width lesser than $0.2 \mathrm{~mm}$. The bottom side of the panel having crack propagation and crack width as shown in Fig. 8.

\section{CONCLUSION}

The GGBFS incorporates geopolymer compressive strength is higher than only fly ash incorporated geopolymer mortar with the range of $8.3 \%$ to $20.6 \%$. The crumb rubber inclusion reduces strength which could be compensating by adding Nano fly ash into the mix. The problem of site application of geopolymer due to difficulties in heat curing can be solved by GGBFS incorporation even under ambient curing.

The water absorption percentage of all the geopolymer mortars is in the acceptable range, but these values are slightly higher than that of control specimen according to ASTM C642 provisions.

The rubber addition in mix increases the flexural strength of fly ash and fly ash-GGBFS incorporated panel by 1.143 times and 1.222 times respectively with lesser crack pronouncement. The residual impact strength ratio of Nano fly ash based geopolymer panel is 1.52 , which is higher than all other panel category.

The bending stiffness is higher for FG and NFGR panel with the values of $31.3 \times 10^{6}$ and $31.46 \times 10^{6} \mathrm{~N}-\mathrm{mm}^{2}$ respectively.

From these findings of results, these panels can be applied for secondary elements in structural application, railway sleeper casting, roof and pavement slab and floor decking slab, etc.

\section{Summary}

Fly ash and waste rubber tire are industrial wastes which are discarded in enormous amounts every year. The global annual ash production is 500 million tons by mass, $75 \%-80 \%$ of which are composed of fly ash. Similarly, recycling of waste rubber tire is a challenging task because of its highly complex chemical structure but the reuse technology is applicable in various fields including building construction. Rubber is a waste material which gives elastic property and ductility. The size of rubber with $30 \& 40$ meshes is appropriated for their uses in building construction. It is used as a partial substitute for sand. Treated rubber shows best performance in concrete strength and stiffness. Fly ash consists almost same that of cement properties and it has the tendency to give higher strength. Fly ash is selected as geo material because of their low percentage of carbon, indicated by low loss on ignition values. Its efficiency in strength increment will be increased by convert macro fly ash into Nano size fly ash. GGBFS is also called as hydraulic cement. So, it will equalize the cement properties which help in cement replacement and strength enhancement. These two materials involve the reduction in amount of $\mathrm{CO}_{2}$ into the atmosphere. So, they are called as ecofriendly materials. Ferrocement is a good innovation for concrete structures. The mesh in the concrete contributes to the load and strength parameters. Expanded metal mesh is selected for their higher load bearing capacity. The expanded metal mesh with chicken mesh layers are to be bundled and cover by geopolymer mortar. This project has its own application in sleepers, precast members and open cover roof top of the buildings. Nano materials are used now a day for their advancement in structural performance. Eventually, Nano materials involve increment in strength and durability. We are decided to use Nano fly ash to obtain superior improvement in the geopolymer ferrocement slab panel. Nano fly ash helps to fills up the pores in specimen and making the element as much denser. The effectiveness of fly ash, Nano fly ash, mesh reinforcement, GGBFS and rubber in geopolymer ferrocement slab panel is appropriate for enhancing the flexure strength of the slab panel.

\section{Future scope}

This research work can be suited for prefabricated roof panel used for boat, wind tunnels, biogas digesters, floor decks, small deck bridges, geotechnical centrifuge enclosure and concrete pavement overlay.

\section{REFERENCES}

1. Al-Azzawi, M., Yu, T., Hadi, M. N. S., "Factors Affecting the Bond Strength Between the Fly Ash-based Geopolymer Concrete and Stee Reinforcement." Structures, Vol. 14, 2018, pp. 262-272, DOI: 10.1016/j.istruc.2018.03.010.

2. Al-Kubaisy, M. A., Jumaat, M. Z., "Flexural behaviour of reinforced concrete slabs with ferrocement tension zone cover." Construction and Building Materials, Vol. 14, 2000, pp. 245-252, DOI 10.1016/S0950-0618(00)00019-2.

3. Cheah, C. B., Ramli, M., "The structural behaviour of HCWA ferrocement reinforced concrete composite slabs." Composites: Part B, Vol. 51, 2013, pp. 68-78, DOI: 10.1016/j.compositesb.2013.02.042.

4. Chithambaram, S. J., Kumar, S., "Flexural behaviour of bamboo based ferrocement slab panels with flyash." Construction and Building Materials, Vol. 134, 2017, pp. 641-648, DOI: 10.1016/j.conbuildmat.2016.12.205.

5. Deb, P. S., Nath, P., Sarker, P. K., "The effects of ground granulated blast-furnace slag blending with fly ash and activator content on the workability and strength properties of geopolymer concrete cured at ambient temperature." Materials and Design, Vol. 62, 2014, pp 32-39, DOI: 10.1016/j.matdes.2014.05.001.

6. Elyamany, H. E., Elmoaty, A. E. M. A., Elshaboury, A. M., "Setting time and 7-day strength of geopolymer mortar with various binders.' Construction and Building Materials, Vol. 187, 2018, pp. 974-983, DOI: 10.1016/j.conbuildmat.2018.08.025.

7. Fan, F., Liu, Z., Xu, G., Peng, H., Cai, C. S., "Mechanical and thermal properties of fly ash based geopolymers." Construction and Building Materials, Vol. 160, 2018, pp. 66-81, DOI: 10.1016/j.conbuildmat.2017.11.023.

8. Kwasny, J., Soutsos, M. N., McIntosh, J. A., Cleland, D. J., "Comparison of the effect of mix proportion parameters on behaviour of geopolymer and Portland cement mortars." Construction and Building Material, Vol. 187, 2018, pp. $635-651$,

DOI: 
10.1016/j.conbuildmat.2018.07.165

9. Li, Z., Li, S., "Carbonation resistance of fly ash and blast furnace slag based geopolymer concrete." Construction and Building Materials, Vol. 163, 2018, pp. 668-680, DOI: 10.1016/j.conbuildmat.2017.12.127.

10. Luga, E., Atis, C. D., "Optimization of heat cured fly ash/slag blend geopolymer mortars designed by "Combined Design" method: Part 1." Construction and Building Materials, Vol. 178, 2018, pp. 393-404, DOI: 10.1016/j.conbuildmat.2018.05.140.

11. Mali, P. R., Datta, D., "Experimental evaluation of bamboo reinforced concrete slab panels." Construction and Building Materials, Vol. 188, 2018, pp. 1092-1100, DOI: 10.1016/j.conbuildmat.2018.08.162.

12. Mousavi, S. E., "Flexural response and crack development properties of ferrocement panels reinforced with steel fibers." Journal of Building Engineering, Vol. 12, 2017, pp. 325-331, DOI 10.1016/j.jobe.2017.06.010.

13. Mucsi, G., Szenczi, A., Nagy, S., "Fiber reinforced geopolymer from synergetic utilization of fly ash and waste tire." Journal of Cleaner Production, Vol. 178, 2018, pp. 429-440, DOI: 10.1016/j.jclepro.2018.01.018.

14. Naskar, S., Chakraborty, A. K., "Effect of nano materials in geopolymer concrete." Perspectives in Science, Vol. 8, 2016, pp. 273-275, DOI: 10.1016/j.pisc.2016.04.049.

15. Park, Y., Abolmaali, A., Kim, Y. H., Ghahremannejad, M. "Compressive strength of fly ash-based geopolymer concrete with crumb rubber partially replacing sand." Construction and Building Materials, Vol. 118, 2016, pp. 43-51. DOI 10.1016/j.conbuildmat.2016.05.001.

16. Patel, Y. J., Shah, N., "Enhancement of the properties of Ground Granulated Blast Furnace Slag based Self Compacting Geopolyme Concrete by incorporating Rice Husk Ash." Construction and Building Materials, Vol. 171, 2018, pp. 654-662, DOI: 10.1016/j.conbuildmat.2018.03.166.

17. Saha, S., Rajasekaran, C., "Enhancement of the properties of fly ash based geopolymer paste by incorporating ground granulated blast furnace slag." Construction and Building Materials, Vol. 146, 2017, pp. 615-620, DOI: http: 10.1016/j.conbuildmat.2017.04.139.

18. Samantasinghar, S., Singh, S. P., "Effect of synthesis parameters on compressive strength of fly ash-slag blended geopolymer." Construction and Building Materials, Vol. 170, 2018, pp. 225-234, DOI: 10.1016/j.conbuildmat.2018.03.026.

19. Shaaban, I. G., Shaheen, Y. B., Elsayed, E. L., Kamal, O. A., Adesina, P. A., "Flexural characteristics of lightweight ferrocement beams with various types of core materials and mesh reinforcement." Construction and Building Materials, Vol. 171, 2018, pp. 802-816, DOI: 10.1016/j.conbuildmat.2018.03.167.

20. Shang, J., Dai, J. G., Zhao, T. J., Guo, S. Y., Zhang, P., Mu, B., "Alternation of traditional cement mortars using fly ash-based geopolymer mortars modified by slag." Journal of Cleaner Production, Vol. 203, 2018, pp. 746-756, DOI: 10.1016/j.jclepro.2018.08.255

21. Temuujin, J., Riessen, A. V., MacKenzie, K. J. D., "Preparation and characterisation of fly ash based geopolymer mortars." Construction and Building Materials, Vol. 24, 2010, pp. 1906-1910, DOI: 10.1016/j.conbuildmat.2010.04.012.

22. Tudjono, S., Purwanto, Apsari K. T., "Study the effect of adding nano fly ash and nano lime to compressive strength of mortar." Procedia Engineering, Vol. 95, 2014, pp. $426-432$, DOI: 10.1016/j.proeng.2014.12.202.

23. VenuMadhav, T., Reddy, I. V. R., Ghorpade, V.G., Jyothirmai, S., "Compressive strength study of geopolymer mortar using quarry rock dust." Materials Letters, Vol. 231, 2018, PP. 105-108, DOI: 10.1016/j.matlet.2018.07.133.

24. Wardhono, A., Gunasekara, C., Law, D. W., Setunge, S., "Comparison of long-term performance between alkali activated slag and fly ash geopolymer concretes." Construction and Building Materials, Vol. 143, 2017, pp. 272-279, DOI: 10.1016/j.conbuildmat.2017.03.153.

25. Wongsa, A., Vanchai, S., Nematollahi, B., Sanjayan, J., Chindaprasirt, P., "Mechanical and thermal properties of lightweight geopolymer mortar incorporating crumb rubber." Journal of Cleaner Production, Vol. 195, 2018, pp. 1069-1080, DOI: 10.1016/j.jclepro.2018.06.003.

26. ACI 549.1R-93-Guide for the Design, Construction, (Reapproved 1999) and Repair of Ferro cement.

27. ACI 549R-97-State-of-the-Art Report on Ferro cement.

28. ASTM D 3043-00 ${ }^{\mathrm{el}}$ - Standard Test Methods for Structural Panels in Flexure.
29. ASTM C1018-97-Standard Test Method for Flexural Toughness and First Crack Strength of Fiber-Reinforced Concrete (Using Beam with Third-Point Loading).

\section{AUTHORS PROFILE}

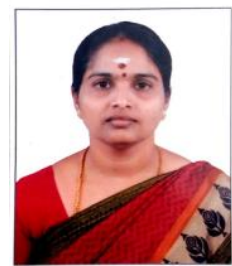

Dr.R.Mohana. M.E.,PhD, Assistant Professor(SG) Department of Civil Engineering,Mepco Schlenk Engineering College, Sivakasi.. The overarching goal of her research is to understand and develop new types of materials and structural systems that will lead to technological advancement of our society in terms of efficient engineering, sustainable infrastructure and overall improved quality of life.

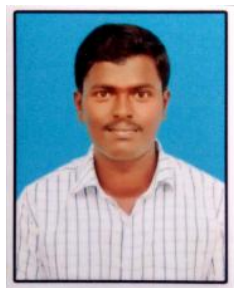

Muthukumar A, M.E., Structural Engineering, Mepco Schlenk Engineering College, Sivakasi. No of Publications- International Journal of Recent Trends in Engineering and Research (IJRTER)-1, ISTE student chapter membership, secured second rank in structural engineering stream. 